\title{
Evaluation of New Wheat Genotypes at Different Dates of Sowing under Irrigated Conditions of Central Brahmaputra Valley Zone of Assam
}

\author{
T. P. Saikia ${ }^{1^{*}}$, P. K. Bordoloi ${ }^{2}$ and B. Kalita ${ }^{1}$ \\ ${ }^{1}$ Department of Agronomy, ${ }^{2}$ Department of Plant Breeding, Regional Agricultural Research \\ Station, AAU, Shillongani, Nagaon, Assam, PIN-782002, India \\ *Corresponding author
}

\section{A B S T R A C T}

\section{Keywords}

Wheat entries, Sowing date, phenophases, Grain yield, Biomass yield, Assam

\section{Article Info}

\section{Accepted:}

15 January 2021

Available Online:

10 February 2021
Wheat is the most important grain crop worldwide based on acreage and is ranked second when it comes to the total production volume. Wheat is the second most important staple crop in India after rice. Because of its wider adaptability it is grown from temperate irrigated to dry and high rainfall areas and from warm humid to dry cold environment. Optimum date of sowing is an important parameter, which affect the growth and yield attributes of wheat among other cultivation practices. To find out optimum date of sowing for Six wheat variety HS 562, HD 2967, HD 3086, HI1544, MACS 6222 and WR 544 was done at four different dates viz. $5^{\text {th }}$ November, $25^{\text {th }}$ November, $15^{\text {th }}$ December and $5^{\text {th }}$ January with row spacing of $20 \mathrm{~cm}$ as per treatments at experimental farm of Regional Agricultural Research Station (RARS), Assam Agricultural University (AAU), Nagaon, Assam, India. From the experiment, it was found that number of days to attain physiological maturity, Av. plant height $(\mathrm{cm})$, Stand Count/sq.m, Number of ear heads /sq. m, Number of grain/ear head, 1000 grains weight (g), grain yield as well as biomass yield was significantly influenced. The crop sown under late sown condition took a smaller number of days to attain maturity in comparison to the crop sown timely. Maximum reduction in grain yield and biomass yield was found for the crop sown after $25^{\text {th }}$ November onwards. The decreasing of yield attributes of the all six entries of wheat probably because of high temperature at the reproductive stage during the crop growing season.

\section{Introduction}

Wheat is the most important grain worldwide based on grain acreage and is ranked second when it comes to the total production volume. The global amount of wheat produced came to about 765.41 million metric tons in crop year
2019-2020. Wheat is the second most important staple crop in India after rice. Because of its wider adaptability it is grown from temperate irrigated to dry and high rainfall areas and from warm humid to dry cold environment. Because of its complex genome nature, it has wider adaptability. 
Being a C3 type crop, it thrives well in cool environment. In India it is grown in 30.63 million hectares area with total production of 99.7 million tones during the season 201718(Agriculture at a Glance 2018). Wheat is the second staple diet of the people of Assam next to rice. It contributes $14.4 \%$ to the value added in agriculture and $3.1 \%$ to GDP (Anon., 2010).

Seasonal fluctuations in temperature have potential impacts on the phasic development and grain yield of crops. Wheat, being a winter cereal, requires particular environmental conditions for better emergence, growth and flowering (Dabre et al., 1993) and is more vulnerable if exposed to high temperatures during reproductive stages (Kalra et al., 2008). Too early sowing produces weak plants with poor root system, which leads to irregular germination, frequent death of the embryo and decomposition of endosperm due to activities of bacteria or fungi (Paul, 1992). The local climate and associated micro meteorological variations are key factors in optimizing the date of sowings in a particular location because the relations between maximum temperature and sowing date gives best predictions of the growth intervals in various wheat growing areas (French et al., 1979). Earlier reports also emphasized the need of studying response of crops to weather variations for evaluating the impact of seasonal temperature change and estimating yield dependence of temperature rise of crops (Kalra et al., 2008). In case of delayed sowing the wheat crop is exposed to low temperature at the time of establishment and exposed to high temperature at the reproductive phase that finally leads to forced maturity. Optimum date of sowing is important parameters which affect the growth and yield attributes of wheat among other cultivation practices. Temperature is an important weather parameter that influences the growth and phenophases of wheat. Plants have definite temperature requirement before attaining a certain phenological stages. Therefore, the optimization of sowing time is an important parameter to attain maximum yield and efficient conversion of biological yield into economic yield. The optimization of exact date of sowing can be done through a comprehensive study on days taken to attain different phenophases, growing degree day's requirement and yield response of wheat crop during rabi season. Therefore, an experiment was planned to have knowledge the exact date sowing of wheat in Assam condition.

\section{Materials and Methods}

The present investigation was carried out at experimental farm of Regional Agricultural Research Station (RARS), AAU, Nagaon, Assam, India. Geographically this centre is situated at $26^{\circ} 21^{\prime} 26.49^{\prime} ' \mathrm{~N}$ latitude and $92^{\circ} 37^{\prime} 51.24^{\prime \prime} \mathrm{E}$ longitude of Central Brahmaputra Valley Zone of Assam. The elevation of this place from mean sea level is 50.2 meter. The climate of RARS comprises of sub humid to sub tropical with hot dry summers and cool winters. Generally, the monsoon sets in around first week of June and lasts upto September end. The mean annual rainfall is $180 \mathrm{~cm}$. The Maximum temperature generally rises up to ${ }^{\circ} \mathrm{C}$ and minimum temperature can be low as ${ }^{\circ} \mathrm{C}$. The experiment was conducted during rabi season of 2018- 19 and 2019-20. The soil of the experimental site was sandy loam soil with $\mathrm{pH} 5.4$, organic carbon recorded $0.92 \%$, available nitrogen medium (305.4 kg/ha), available $\mathrm{P}_{2} \mathrm{O}_{5}$ low (19.5 kg/ha) and available $\mathrm{K}_{2} \mathrm{O}$ recorded medium (126.9 kg/ha). The experiment was laid in factorial randomized plot design (RBD) with three replications. Size of each plot was 4 $\mathrm{m} \times 3 \mathrm{~m}=12 \mathrm{~m}^{2}$. Sowing of Six wheat variety HS 562, HD 2967, HD 3086, HI1544, MACS 6222 and WR 544was done at four different dates viz. $5^{\text {th }}$ November, $25^{\text {th }}$ November, $15^{\text {th }}$ December and $5^{\text {th }}$ Januarywith row spacing of 
$20 \mathrm{~cm}$ as per treatments. Four irrigations were applied at four critical phenological stages of wheat. The crop was fertilized at the rate of $120 \mathrm{~kg} \mathrm{~N}, 60 \mathrm{~kg} \mathrm{P}_{2} \mathrm{O}_{5}$ and $40 \mathrm{~kg} \mathrm{~K}_{2} \mathrm{O}$. Out of which, $1 / 3$ rd $\mathrm{N}$ and full dose of $\mathrm{P}_{2} \mathrm{O}_{5}$ and $\mathrm{K}_{2} \mathrm{O}$ were applied as basal dose at the time sowing by broadcasting method.

The remaining 2/3rd dose of $\mathrm{N}$ were applied in two splits at CRI and late tillering stages. The yield and yield attributing characteristic were noted by regular field inspection method. Meteorological data, viz., maximum and minimum temperature, relative humidity, monthly rainfall, hours, days of Rainfall etc, were recorded from Agro-meteorological observatory of the research station.

\section{Results and Discussion}

During the experimentation period in the year 2018-19 the rainfall recorded $4.2 \mathrm{~mm}$ to 181.8 $\mathrm{mm}$ and highest rainy days received in the month of April. However, in the year 2019-20 the rainfall recorded ranges from $1 \mathrm{~mm}$ to 67.9 and rainy days highest received in the month of April which was lowest as compared to the previous year. The Maximum temperature received ranges $24.4^{\circ} \mathrm{C}$ to $29^{\circ} \mathrm{C}$ and minimum temperature ranges $8.3^{\circ} \mathrm{C}$ to $18{ }^{\circ} \mathrm{C}$ in the year 2018-19. Similarly, maximum temperature received ranges $22.7^{\circ} \mathrm{C}$ to $30.5^{\circ} \mathrm{C}$ and minimum temperature ranges $8.7^{0} \mathrm{C}$ to $16.6^{\circ} \mathrm{C}$ in the year 2019-20 (Table 1). Average plant height among the entries was observed highest in $05^{\text {th }}$ November sowing as compared to the three sowing times. From the Table 2 it has been observed that as the sowing that shifted toward the month of January the average plant height has been observed lower as compared to the $5^{\text {th }}$ November sowing for all the entries. This might be due to the impact of lower value of night and day temperature during the sowing time of the wheat crop. Similarly, highest plant height $(94.93 \mathrm{~cm})$ recorded in the entry HS 562 as compared to the other entries in all four dates of sowing. Plant population of the all entries were recorded highest in $5^{\text {th }}$ November sowing as compared to the other three date of sowing (Table 1), this might be due to the cold injury during germination of the wheat seedling from the $3^{\text {rd }}$ week of November to first week January.

Number of ear head has been recorded highest in first sowing date in the all entries as compared to the rest three date of sowing respectively (Table 1), this might be due to the decreases effective tiller number/hill of the all entries of wheat. Therefore, from the experiment it can be stated that beyond $5^{\text {th }}$ November date of sowing leads to lower down the effective tiller numbers of the wheat entries. Similar finding has been reported by Haq\& Khan, (2002) and Tahir et al., (2009) that late planting affects germination, growth, grain development and produces poor tillering due to winter injury in low temperature.

Highest number of grain/ear head (45.97) recorded in the entry HS 562 as compared to the other entries in all four dates sowing. Likewise, highest number of grain/ear head of the all entries were recorded in $5^{\text {th }}$ November sowing as compared to the other three date of sowing (Table 3).

The grain yield and biomass yield were recorded highest in the entry HS 562 as compared to the other entries in $5^{\text {th }}$ November dates of sowing and gradual decreasing trend has been observed in all entries as compared to other date of sowing (Table 3). This might be due to delayed sowing the wheat crop was exposed to low night and day temperature at the time of establishment and exposed to high day and night temperature at the reproductive phase that finally leads to forced maturity. Singh and Uttam (1999) reported estimated yield loss @ $39 \mathrm{~kg} \mathrm{ha}^{-1}$ day $^{-1}$ in each delay in sowing from the optimum sowing time. 
Table.1 Agro meteorological data of the station during the crop season in 2018-19 to 2019-20

\begin{tabular}{|c|c|c|c|c|c|c|c|c|}
\hline \multirow{2}{*}{ Year } & \multicolumn{2}{|c|}{ Rain Fall (mm) } & \multicolumn{2}{|c|}{ Rainy Days } & \multicolumn{2}{|c|}{$\operatorname{Max} \operatorname{Tem}\left({ }^{0} \mathrm{C}\right)$} & \multicolumn{2}{|c|}{ Min Tem $\left({ }^{0} \mathrm{C}\right)$} \\
\hline & 2018-19 & 2019-20 & 2018-19 & 2019-20 & 2018-19 & 2019-20 & 2018-19 & 2019-20 \\
\hline November & 12.2 & 4 & 4 & 2 & 27.6 & 28.8 & 15.3 & 16.6 \\
\hline December & 28.2 & 1 & 2 & 1 & 25 & 23.9 & 11.2 & 9.7 \\
\hline January & 4.2 & 18 & 2 & 5 & 24.4 & 22.7 & 8.3 & 8.7 \\
\hline February & 17.2 & 39.3 & 4 & 4 & 25.3 & 24.6 & 11.8 & 9.9 \\
\hline March & 46 & 4.7 & 8 & 3 & 27.9 & 29 & 14.9 & 14.6 \\
\hline April & 181.8 & 67.9 & 14 & 11 & 29 & 30.5 & 18 & 16 \\
\hline
\end{tabular}

Table.2 Plant height $(\mathrm{cm})$, final stand count/ sq $\mathrm{m}$ and number of ear head/ sq $\mathrm{m}$ of wheat entries in different date of sowings (pooled of year 2018-19 and 2019-20)

\begin{tabular}{|c|c|c|c|c|c|c|c|c|c|c|c|c|}
\hline \multirow[t]{3}{*}{ Treatment } & \multicolumn{4}{|c|}{ Av. plant height(cm) } & \multicolumn{4}{|c|}{ Stand Count/sq.m. } & \multicolumn{4}{|c|}{ No of ear heads /sq m } \\
\hline & \multicolumn{12}{|c|}{ Sowing date } \\
\hline & $\begin{array}{l}\text { 05th } \\
\text { Nov }\end{array}$ & $\begin{array}{l}\text { 25th } \\
\text { Nov }\end{array}$ & $\begin{array}{l}\text { 15th } \\
\text { Dec }\end{array}$ & $\begin{array}{l}\text { 05th } \\
\text { Jan }\end{array}$ & $\begin{array}{l}\text { 05th } \\
\text { Nov }\end{array}$ & $\begin{array}{l}\text { 25th } \\
\text { Nov }\end{array}$ & 15th Dec & 05th Jan & $\begin{array}{l}\text { 05th } \\
\text { Nov }\end{array}$ & $\begin{array}{l}\text { 25th } \\
\text { Nov }\end{array}$ & $\begin{array}{l}\text { 15th } \\
\text { Dec }\end{array}$ & $\begin{array}{c}\text { 05th } \\
\text { Jan }\end{array}$ \\
\hline HS 562 & 94.93 & 92.00 & 91.67 & 80.20 & 187.33 & 162.67 & 152.00 & 143.67 & 257 & 210 & 184 & 181 \\
\hline HD 2967 & 97.53 & 93.40 & 91.67 & 81.13 & 207.33 & 196.00 & 195.33 & 190.67 & 258 & 250 & 246 & 216 \\
\hline HD 3086 & 92.47 & 91.60 & 91.33 & 80.20 & 202.33 & 177.67 & 173.33 & 189.33 & 268 & 249 & 240 & 234 \\
\hline HI1544 & 89.87 & 89.20 & 88.67 & 73.87 & 206.67 & 183.33 & 174.00 & 176.33 & 259 & 247 & 248 & 238 \\
\hline MACS 6222 & 92.13 & 91.33 & 90.73 & 77.87 & 196.33 & 149.67 & 146.00 & 143.67 & 276 & 240 & 235 & 223 \\
\hline WR 544 & 90.97 & 89.93 & 89.60 & 84.07 & 207.33 & 181.33 & 178.67 & 166.00 & 253 & 245 & 239 & 230 \\
\hline \multicolumn{13}{|c|}{ Sowing date } \\
\hline $\mathbf{C V}$ & 1.86 & & & & & & & & 4.80 & & & \\
\hline CD (0.05) & 1.05 & & & & & & & & 9.48 & & & \\
\hline \multicolumn{13}{|c|}{ Variety } \\
\hline CV & 2.31 & & & & & & & & 4.63 & & & \\
\hline CD (0.05) & 1.31 & & & & & & & & 9.24 & & & \\
\hline \multicolumn{13}{|c|}{ Sowing date $\mathrm{X}$ Variety } \\
\hline $\mathbf{C V}$ & 4.69 & & & & & & & & 18.70 & & & \\
\hline CD (0.05) & 2.71 & & & & & & & & 6.48 & & & \\
\hline
\end{tabular}


Table.3 Yield and yield attributing characteristic of wheat entries in different date of sowings (pooled of year 2018-19 and 2019-20)

\begin{tabular}{|c|c|c|c|c|c|c|c|c|c|c|c|c|}
\hline \multirow[t]{3}{*}{ Treatment } & \multicolumn{4}{|c|}{ No of grain/earhead } & \multicolumn{4}{|c|}{ Biomass yield (q/ha) } & \multicolumn{4}{|c|}{ Yield (q/ha) } \\
\hline & \multicolumn{12}{|c|}{ Sowing date } \\
\hline & $\begin{array}{l}\text { 05th } \\
\text { Nov }\end{array}$ & $\begin{array}{l}25 \text { th } \\
\text { Nov }\end{array}$ & $\begin{array}{l}15 \text { th } \\
\text { Dec }\end{array}$ & $\begin{array}{c}\text { 05th } \\
\text { Jan }\end{array}$ & $\begin{array}{l}\text { 05th } \\
\text { Nov }\end{array}$ & $\begin{array}{l}25 \text { th } \\
\text { Nov }\end{array}$ & $\begin{array}{l}\text { 15th } \\
\text { Dec }\end{array}$ & $\begin{array}{c}\text { 05th } \\
\text { Jan }\end{array}$ & 05th Nov & $\begin{array}{l}\text { 25th } \\
\text { Nov }\end{array}$ & $\begin{array}{l}15 \text { th } \\
\text { Dec }\end{array}$ & 05th Jan \\
\hline HS 562 & 45.97 & 41.43 & 46.54 & 33.44 & 121.44 & 91.66 & 88.43 & 55.81 & 48.37 & 36.26 & 34.95 & 20.06 \\
\hline HD 2967 & 38.14 & 34.80 & 34.12 & 24.23 & 108.85 & 91.15 & 84.64 & 51.13 & 43.25 & 36.05 & 33.41 & 18.10 \\
\hline HD 3086 & 41.01 & 39.61 & 38.68 & 40.72 & 118.99 & 105.70 & 100.24 & 83.98 & 47.37 & 41.97 & 39.75 & 33.14 \\
\hline HI1544 & 35.25 & 34.49 & 33.12 & 31.89 & 97.91 & 92.45 & 89.06 & 75.88 & 38.80 & 36.58 & 35.20 & 29.85 \\
\hline MACS 6222 & 34.00 & 36.20 & 34.37 & 32.68 & 101.26 & 93.73 & 85.98 & 68.75 & 40.16 & 37.10 & 33.95 & 26.95 \\
\hline WR 544 & 30.17 & 27.94 & 27.45 & 29.54 & 90.29 & 81.27 & 80.22 & 73.83 & 35.70 & 32.04 & 31.61 & 29.01 \\
\hline \multicolumn{13}{|c|}{ Sowing date } \\
\hline CV & 2.62 & & & & 7.12 & & & & 8.37 & & & \\
\hline CD (0.05) & 0.82 & & & & 4.24 & & & & 2.39 & & & \\
\hline \multicolumn{13}{|c|}{ Variety } \\
\hline $\mathbf{C V}$ & 2.78 & & & & 8.14 & & & & 6.79 & & & \\
\hline CD (0.05) & 0.89 & & & & 5.19 & & & & 1.95 & & & \\
\hline \multicolumn{13}{|c|}{ Sowing date $X$ Variety } \\
\hline CV & 1.85 & & & & 17.62 & & & & 17.38 & & & \\
\hline CD (0.05) & 0.58 & & & & 10.38 & & & & 10.25 & & & \\
\hline
\end{tabular}


Table.4 1000 Grains weight (g) and physiological maturity of wheat entries in different date of sowings (pooled of year 2018-19 and 2019-20

\begin{tabular}{|c|c|c|c|c|c|c|c|c|}
\hline \multirow[t]{3}{*}{ Treatment } & \multicolumn{4}{|c|}{1000 Grains Weight ( g) } & \multicolumn{4}{|c|}{$\begin{array}{c}\text { Physiological Maturity } \\
\text { (Days after seeding) }\end{array}$} \\
\hline & \multicolumn{8}{|c|}{ Sowing date } \\
\hline & 05th Nov & 25th Nov & 15th Dec & 05th Jan & 05th Nov & 25th Nov & 15th Dec & 05th Jan \\
\hline HS 562 & 40.84 & 41.61 & 40.99 & 33.62 & 125.67 & 126.00 & 112.67 & 100.67 \\
\hline HD 2967 & 43.72 & 41.30 & 39.65 & 35.02 & 136.00 & 135.67 & 120.67 & 107.33 \\
\hline HD 3086 & 42.81 & 42.37 & 42.67 & 35.00 & 115.33 & 121.33 & 109.67 & 96.67 \\
\hline HI1544 & 42.22 & 42.63 & 42.70 & 39.28 & 116.00 & 120.67 & 103.67 & 96.33 \\
\hline MACS 6222 & 42.48 & 42.66 & 42.27 & 37.08 & 121.33 & 124.00 & 111.00 & 97.00 \\
\hline WR 544 & 46.43 & 46.47 & 47.77 & 42.62 & 109.00 & 107.33 & 102.00 & 93.67 \\
\hline \multicolumn{9}{|c|}{ Sowing date } \\
\hline $\mathbf{C V}$ & 2.72 & & & & 1.79 & & & \\
\hline CD (0.05) & 0.92 & & & & 1.01 & & & \\
\hline \multicolumn{9}{|c|}{ Variety } \\
\hline $\mathrm{CV}$ & 2.88 & & & & 1.98 & & & \\
\hline CD (0.05) & 0.99 & & & & 1.23 & & & \\
\hline \multicolumn{9}{|c|}{ Sowing date X Variety } \\
\hline $\mathrm{CV}$ & 1.95 & & & & 3.98 & & & \\
\hline CD (0.05) & 0.68 & & & & 2.47 & & & \\
\hline
\end{tabular}


Normal sowing prolongs the duration of tillering (Ishag, 1994) and produced a greater number of tillers, number of spikes, grains/spike and grain weight that ultimately boosts up grain and straw yields (Qasim et al., 2008). Rajput and Verma, (1994) also observed that normal sowing time gave higher grain yield than late sowing. The numbers of days taken to attain different phenophases, decreases with delay in sowing that resulted into reduced life span of late sown crop. Similar findings have been also reported by Gupta et al., (2017). Similarly, in test weight, there has been observed significant differences among the entries and in different date of sowing, respectively (Table 4). The highest physiological maturity (days after seeding) days has been recorded in the all the entries during first date of sowing as compared to the other date of sowing in all entries. From the above findings it can be concluded that date of sowing has significant influence on growth and yield attributes of wheat crop. In case of wheat, date of sowing is most important factors that governs the phenological development of crop and also efficient conversion of biomass into economic yield. It has been observed that the wheat crop sown at normal date usually have longer crop duration thus they get an opportunity to accumulate more biomass as compared to late sowing and thus it finally resulted in higher grain yield and biological yield.

\section{References}

Agriculture at a glance. 2018. Retrieved from: http://agricoop.gov.in/sites/default/files /agristatglance2018.pdf

Dabre, W.M., S.B. Lall and G.L. Ingole. 1993. Effects of sowing dates on yield ear number, stomatal frequency and stomatal index in wheat. $J$. Maharashtra Agric. Univ. 18: 64-66.

French, R.J., J.E. Schultz and C.L. Rudd. 1979. Effect of time of sowing on wheat phenology in South Australia. Australian J. Expt Agric. Animal Husb., 19(96): 89-96.

Gupta, S., Singh, R.K., Sinha, N. K., Singh, A and Shahi, U. P. 2017. Effect of different sowing dates on growth and yield attributes of wheat in Udham Singh Nagar district of Uttarakhand, India. Plant Archives. 17 (1): 232-236.

Haq, N.U. and M. Khan. 2002. Effect of planting date, chlortoluran + MCPA and wheat varieties on weed control and wheat yield. Sarhad J. Agric., 18(2): 443-447.

Ishag, H.M. 1994. Genotype differences in heat stressed wheat in the irrigated Gezira Scheme. In: Wheat in HeatStressed Environments: Irrigated dry areas and Wheat-Rice Farming Systems. (Eds.): D.A. Saunders and G.H. Hottel. Proc. International conference of wheat in hot, dry irrigated environments. Wad Medani; Sudan, 14 February, 1993, pp. 170174.

Kalra, N., D. Chakraborty, A. Sharma, H.K. Rai, M. Jolly, S. Chander, P.R. Kumar, S. Bhadraray, D. Barman, R.B. Mittal, M. Lal and M. Sehgal. 2008. Effect of increasing temperature on yield of some winter crops in northwest India. Current Sci., 94(1): 82-88.

Paul, S.R. 1992. Effects of pre-sowing treatments, seed rates, fertility levels and surface soil competition on growth and yield at late sown rain-fed wheat in Assam. Agric. Res., 13:410-411.

Qasim, M., M. Qamer, Faridullah and M. Alam. 2008. Sowing dates effect on yield and yield components of different wheat varieties. J. Agric. Res., 46(2): 135-140.

Rajput, R.L. and Verma. 1994. Effect of sowing dates on the yield of different varieties of wheat in Chambal Command Area of Madhya Pradesh 
Bharyiya Krishi AnusandhanPatrika. Tahir M, Ali A, Nadeem MA, Hussain A, Ind. J. Agron., 9: 165-169. Khalid F. 2009. Effect of different

Singh, V.P.N. and S.K. Uttam. 1999. sowing dates on growth and yield of Influence of sowing dates on yield of wheat cultivars under saline sodic conditions in Central Utter Pradesh. Ind. Agric., 38(1): 64-68. wheat (Triticum aestivumL.) varieties in District.Jhang, Pakistan. Pak J Life Soc Sci. 7(1): 66-69

\section{How to cite this article:}

Saikia, T. P., P. K. Bordoloi and Kalita, B. 2021. Evaluation of New Wheat Genotypes at Different Dates of Sowing under Irrigated Conditions of Central Brahmaputra Valley Zone of Assam. Int.J.Curr.Microbiol.App.Sci. 10(02): 1753-1760.

doi: https://doi.org/10.20546/ijcmas.2021.1002.207 